\title{
WHISTLEBLOWERS' ROLE IN MITIGATING FRAUD OF MALAYSIAN HIGHER EDUCATION INSTITUTIONS
}

\author{
Kristine Belaja, Intan Salwani Mohamed* and Nabilah Rozzani
}

\begin{abstract}
Research aim: The current study aims to discuss possible fraud occurrences that might happen in the setting of Malaysia higher education sector, as well as exploring the importance of whistleblowers as the primary source of information to investigators while looking into fraud cases involving universities.
\end{abstract}

Design/ Methodology/ Approach: Literature review method is employed for this study.

Research finding: With the rise of fraud cases in many sectors in Malaysia, many studies are concurrently emphasising on the crucial function of whistleblowing as an internal control mechanism of an organisation. However, the education industry is facing a challenging ethical dilemma with budget cuts experienced by higher education institutions, as they need to survive within the means of these allocations to ensure that they are operating smoothly, and to uphold their reputation.

Theoretical contribution/ Originality: The discussion provided from this study on issues of fraud in Malaysian higher education institution and the vital role for individuals to blow the whistle as soon as they sense red flags is hoped to provide useful guides for organisations in designing distinct and unprejudiced whistleblowing hotlines to stop illegal organisational behaviour internally.

Practitioner/ Policy implication: With fraud cases escalating, especially in universities, this study intends to create awareness among accounting professionals of the merits of whistleblowing to support reporting wrongdoings regarding their peers, possibly even before the effects are so disastrous that an organisation's viability is in question.

Research limitation/Implication: As this is a conceptual paper, the findings are expected to lead towards further understanding of issues, and possible positive impacts on whistleblowing should be gathered and tested empirically.

Keywords: Integrity, Whistleblowing, Higher Education Institutions.

*Corresponding Author: Intan Salwani Mohamed, PhD is a Research Fellow at Accounting Research Institute, Universiti Teknologi MARA, Shah Alam 40450, Malaysia. Email: intan838@salam.uitm.edu.my

Kristine Belaja, is a Diplomatic Administrative Officer in one of the ministries in Malaysia. Email: kbelaja88@gmail.com

Nabilah Rozzani, $\mathrm{PhD}$ is a Senior Lecturer at Faculty of Business Management \& Professional Studies, Management and Science University, Shah Alam 40100, Malaysia. Email: nabilah_rozzani@msu.edu.my 
Type of article: Conceptual paper

JEL Classification: M00, M48

\section{Introduction}

Fraud evokes a visceral response in us. It is an abuse of our belief towards fair treatment among fellow human beings. Whether we act in the response of our principles or egotism, nobody likes to be deceived (Golden, Skalak \& Clayton, 2006). Occupational fraud - being the most common - can be categorised into three types, namely (1) asset misappropriation, (2) financial statement fraud and (3) corruption (ACFE, 2014). Asset misappropriation involves the theft of cash or inventory, skimming revenues, payroll fraud and embezzlement. Occasionally, staff collude with others to commit fraud, such as abetting to vendors' intent on overbilling an organisation (Golden et al., 2006). Financial statement fraud, on the other hand, is categorised by intentional misstatements, omissions of amounts, or disclosures in financial reporting which intends to mislead financial statement users. Specifically, accounting records or supporting documents from the presented financial statements could be manipulated, falsified, or altered (Rezaee, 2002). On the other hand, corruption is an act of giving or receiving gratification or reward in the form of cash or high valued in-kind for performing a task which relates to his or her job description (MACC, 2016).

According to ACFE's Report to the Nations on Occupational Abuse (2014), asset misappropriations is the most common type of fraud, occurring in 85 per cent of cases included in their study, causing a median loss of USD130,000 (the least costly). In comparison, cases which involve financial statement fraud (only 9 per cent of all cases included) affected the United States (U.S.) significantly, with a median loss of USD1 million being experienced by U.S. companies in 2014. Corruption schemes fell in the median, in terms of frequency ( 37 per cent of cases) and median loss of USD200,000 which were suffered by U.S. companies. Conspiracy helps staff to escape independent checks and other anti-fraud controls, hence allowing them to steal larger amounts of money. The median loss of fraud committed by a single person was found to be USD80,000, but these losses surged radically as the number of wrongdoers heightened. For example, in cases involving two wrongdoers, the median loss was USD200,000, while for three wrongdoers, it was USD355,000. Similarly, when there are four or more wrongdoers involved, the median loss exceeded to USD500,000. According to the report, approximately 77 per cent of fraud was committed by individuals working in one of the seven departments: accounts, operations, sales, executive or upper management, customer 
service, purchasing and finance (ACFE, 2014). Malaysia also is not protected from fraud. In 2006, 6,921 commercial crime cases were recorded, with total loss amounting up to RM685 million. These cases include criminal breach of trust, cheating and cybercrime. Also, 2,892 of the cases committed were pertaining to falsification, fake currency notes and credit card offences under the Copyright Act (Auditor General Malaysia, 2008).

Financial scandals in the years 2000 and 2001 involving major organisations, also conflict of interest disputes in the financial services industry had triggered investor's confidence in the stock market to deteriorate melodramatically. The modern society had actively reacted to the upsurge of corporate malfeasance by focusing on maintaining an environment of fair dealing in doing their businesses. Additional laws are conceded; agencies are established to administer them; police with special roles are appointed; ethics and morals are imparted in schools and learned in businesses, and offenders are penalised by the forfeiture of their illegal proceeds and personal right - all with a view to deter, detect, and punish fraud perpetrators (Golden et al., 2006). Corruption cases in Malaysia have been statistically amplified since independence, where the increasing number of convictions shows that corruption reports have become more rampant these days. Nonetheless, the Integrity Commitment Report 20092013 has shown improvements with respect to Malaysia's effort in battling corruption. These efforts include the rebranding of the Anti-Corruption Agency (ACA) to become the Malaysian Anti-Corruption Commission (MACC). The rebranding of this agency was accompanied by improvised organisational structures, increased enforcement capabilities and relative autonomy, as well as more active effort in combating corruption. The Mutual Evaluation Report Malaysia 2015 had also stressed on some recommendations for Malaysian authorities to consider when enhancing effective powers and mechanisms as to enable for smooth sharing of information within multiple agencies (FATF, 2015). Simultaneously, nonenforcement and economic monitoring bodies, such as Bank Negara Malaysia (BNM), Companies Commission of Malaysia (CCM), Securities Commission (SC) and Bursa Malaysia Berhad has also worked with nongovernmental organisations such as Transparency International Malaysia (TI-M) to fight corruption, misappropriation of assets or funds and power abuse in all sectors (Borneo Post Online, 2014).

With the rise of fraud cases in many sectors in Malaysia, whistleblowing study is deemed significant to concurrently emphasising on the vital function of whistleblowing as an internal control mechanism of an organisation (Ghani, Galbreath \& Evans, 2011). Therefore, the 
current study aims to discuss possible fraud occurrences that might happen in the setting of Malaysia higher education sector, as well as exploring the importance of whistleblowers as the primary source of information to investigators while looking into fraud cases involving universities. Whistleblowing is usually not restricted to issues that only affect an individual; it is concerned with issues that affect the whole of society. This is more so to the context of public higher education institutions, as most of its funding comes from taxpayers' money. Issues would arise with regards to public safety, how taxpayers' dollars are spent or alleged violations of public trust (Government Accountability Project, 2019).

In tandem with the emerging issues of corruption and financial scandals in Malaysia today, the current study aims to identify the types of fraud that would be most likely to occur with the setting of Malaysian higher education institution, also to discuss on the role of whistleblowers in mitigating fraud in these institutions. With that, the current study hopes to enhance the literature with regards to the role of whistleblowers in Malaysia and how they can be substantial in mitigating fraud cases. The remainder of the present paper is organised as follows. Section 2 discusses possible fraud instances that might occur in the environment of higher education in Malaysia. Efforts to mitigate fraud, as suggested by various past studies are discussed in Section 3, while the role of whistleblowers as added value in improving the effectiveness of the fraud mitigation framework is described in Section 4. Finally, conclusions drawn from the current study are provided in Section 5 .

\section{Literature Review}

Financial problems occur in the government and non-profit sectors, just as they do in the corporate sector (Weisbrod, 1997). Concerns were recently raised on the responsibilities of charity societies, mainly on the acceptability of their financial reporting and oversight instrument over the past decade. These issues intensified as increasing financial scandals involving these societies become evident to the public (Nasir et al., 2009). Asset misappropriation in United Way of America (Murawski, 1995), investment scam in Foundation for the New Era Philanthropy (Stecklow, 1997), and the unreasonably large compensation package for the president of Adelphi University have jeopardised the subdivision's trustworthiness as a charitable body (Thornburg, 1997). Distinguished and well-known non-profit societies in the USA, such as the American Red Cross and Nature Conservancy, also had to deal with various financial scandals and their subsequent adverse effects. The Red Cross had its reserves 
embezzled and surplus bonuses taken away due to weak internal controls. For the case of Nature Conservancy, they face problems when the institution becomes involved with incongruous business and real estate dealings for its trustees (Eaton \& Akers, 2007). In Malaysia, charity bodies would usually utilise funds which are contributed by the public and revel in tax-exempt status (Othman, Ali \& Omar, 2012). In validating their responsibility to the public, these institutions are supposedly accountable to report evidently how the funds are being used in their operations (Flack \& Ryan, 2005). However, evidence shows that charity bodies are not abided fully by this legal prerequisite (Stittle, 2002).

Even universities are not excluded from getting involved with financial scandals (Cooper, Everett \& Neu, 2005). Most universities frequently become fraud victims due to their unique control environments, i.e. the decentralised control environment. Although public universities are usually large, they may lack of standard internal controls such as lack of segregation of duties and independent oversight to deter or identify fraud, which can increase the risk of fraud (Peltier-Rivest, 2014). Faculty team and staff administrators, who support honesty and collegiality, are usually accountable for handling academic procurements and expenditures, as well as safeguarding institutional assets.

According to the Higher Education Funding Council for England (HEFCE) (2015), several scams and attempted scams relating from counterfeit charges to suppliers' bank account details records have been reported with fraud risk across countries. These scams mostly involve construction companies, where payment to suppliers inclines to be made in larger amounts. In one case, HEFCE reported fraud being suspected of having comprised of several staff members at an institution with the institution's travel supplier, where the collusion had involved the falsification of business class flights as economy class for a research contract. In another case reported by HEFCE, an institution claimed that roughly GBP570,000 was illegally attained by a member of a Finance Office. Payments from suppliers to the institution were diverted into another account controlled by the staff member. Also, a breach of trust involving a senior manager at an institution was reported with regards to payments for undelivered services and equipment. This case of fraud had involved improper payments amounting to GBP300,000 to a consultancy company owned by the senior manager (HEFCE, 2015). Other than that, cases of personal usage of university equipment have also been reported by HEFCE, where a university discovered staff conducting personal work with a university-owned research laboratory, equipment and consumables. Additionally, another university reported conspiracy 
between its senior staff in a small academic unit who had permitted about GBP33,000 worth of institution funds to be claimed as private expenses by a member of staff. Further, according to HEFCE, modified cheques were also one of the deceitful activities reported to the institution, whereby an employee of a university's subsidiary company had diverted, and modified cheques prepared for the company to become billed for himself. A summary of the reported number of scams and attempted scams relating to higher education by HEFCE (2015) can be seen in Table 1.

Table 1. Summary of Scams and Attempted Scams Reported concerning Higher Education Institutions

\begin{tabular}{ll}
\hline $\begin{array}{l}\text { Scams and attempted } \\
\text { scams }\end{array}$ & Cases reported \\
\hline $\begin{array}{l}\text { Counterfeit charges to } \\
\text { suppliers', modification } \\
\text { of bank account details }\end{array}$ & $\begin{array}{l}\text { Involves construction companies where payment to such } \\
\text { suppliers inclines to be larger } \\
\text { Payments for undelivered services and equipment, where } \\
\text { the fraud comprised of inappropriate payments to a } \\
\text { consultancy agency owned by the senior manager of the } \\
\text { university } \\
\text { Several staff members at an institution collude with the } \\
\text { institution's travel supplier to falsify business class flights } \\
\text { for a research contract as economy class. } \\
\text { Conspiracy between senior staff involving falsified claims } \\
\text { on private expenses. } \\
\text { Staff conducting personal work with a university-owned } \\
\text { research laboratory, equipment and consumables. }\end{array}$ \\
\hline Misuse of university's \\
property
\end{tabular}
Source: Higher Education Funding Council for England (HEFCE) (2015)

These cases in England, as depicted in Table 1, are also common in Malaysia. The most common involves staff making a profit or conducting personal work using the university's property and equipment. However, most are not reported, as many Malaysian are still unaware of the role of whistleblowers in providing information regarding fraud in the workplace. In addition, many have the perception that they would be betraying their friends if they come forward and report their wrongdoings. This is very dangerous, considering that the Malaysian higher education institution receives a lot of grants and funding from the government. The Malaysian government has been continuously providing a large percentage of higher education institutions' total funding towards its operating activities and development plan since the formation of the first public university in Malaysia (Nasir, Othman, Said \& Ghani, 2009). Precisely, almost 90 per cent of public higher education institutions acquire funds from the government, while the remaining 10 per cent was obtained from student fees (Ministry of Higher Education, 2015). In the 
2016 national budget, a total of RM 13 billion has been allocated for the Ministry of Higher Education (MOHE), in which RM7 billion from this amount was allocated specifically for the use of public higher education institutions (Ministry of Finance, 2015).

However, it has been recently observed that the amount budgeted for MOHE in 2016 had a significant cut of RM2.4 billion as compared to its allocation in the 2015 national budget (15.3 per cent reduction), with local public universities being burdened by the budget reduction (Ministry of Higher Education, 2015). Excluding Universiti Kebangsaan Malaysia (UKM), a total of 19 out of 20 local public universities experienced budget cuts in 2016, with a majority (over 10 per cent) being notable universities. This includes Malaysia's top-ranked Universiti Malaya (UM) (reduction of 27.3 per cent), as well as Universiti Teknologi MARA (UiTM) (23.7 per cent) and Universiti Malaysia Terengganu (UMT) (23.8 per cent) (Ministry of Finance, 2015). This budget cut might lead to possibilities of fraud in these higher education institutions, as they need to survive within the means of these allocations to ensure that they are operating smoothly, also to uphold their reputation. In order to keep up with the latest advancements in education to facilitate with teaching and learning environment, this budget cut might not be favourable to the financial stability of the universities.

Stone \& Starkey (2011) stated that the decrement in the amount of public money being apportioned to universities stimulates corruption within the higher education system throughout the world. A report by the anti-corruption agency, Transparency International (2013), disclosed that the magnitude of fraud and other categories of unethical conduct in the sector might escalate as a result of deteriorating investment.

"The very structure and culture of colleges and universities, as well as the current constraints under which many...operate, can create conditions that facilitate fraud" (Transparency International October 2013 Global Corruption Report: Education)

\subsection{Efforts to Mitigate Fraud in Malaysian Higher Education Institutions}

As fraud cases are on the rise, most internal audit experts agree that nonprofit institutions' greatest fraud-related challenge is managing reputational risk. This is because these organisations depend mostly on donations based on the organisation being respectable and effective (Jaeggi, 2014). Good faculty members and students would not join fraudulent universities. Governments and donors would not financially contribute to organisations they do not trust. Realising the impact of fraud 
on society, Peltier-Rivest (2014) suggested several precautionary measures in which universities and other non-profits can deter fraud and reputational destruction. These measures include (1) encouraging senior administrators to apply ethical leadership, (2) carrying out consistent fraud risk assessments and executing targeted internal controls, (3) educating faculty and staff members about university's ethics policy and set up anti-fraud training, (4) implementing anonymous reporting mechanism (such as whistleblowing hotline) and feedback procedures among all stakeholders and senior administration, and (5) aligning faculty members' incentives with university's mission and goals. Being the receiver of a considerable amount of public funding, the management of public higher education institutions in Malaysia are responsible to inform the public on how they make use of the funds received (Ismail \& Abu Bakar, 2011). Hence, these precautionary measures need to be implemented consistently in higher education institutions so that the administration of these institutions would provide for effective transparency to the public.

Effective transparency includes the better discovery of unethical situations and reporting the wrongs in the corporate environment. While transparency in financial reporting is the mantra of the day, the means to move towards better transparency remains elusive. Fraud deterrence programmes are especially critical in avoiding and mitigating fraud (Albrecht, Albrecht, Albrecht \& Zimbelman, 2008). Numerous precautionary instruments can be used by organisations, such as antifraud policy, whistleblowing policy, surprise audits, fraud hotline, ethics, fraud training, fraud vulnerability reviews, operational audits, fraud examination department, effective audit committee and disciplinary action (Omar \& Abu Bakar, 2012). It is also believed that the risk of corruption is heightened significantly in environments where the reporting of wrongdoing is not supported or protected (OECD, 2012). However, employees' willingness to provide information regarding any wrongdoings which occur within their organisation would highly depend on their ethical climate.

\subsection{Ethical Climate Theory}

Ethical climate, which refers to employees' perception towards procedures and policies that are relevant to ethical practices in an organisation, is a crucial determinant of ethical behaviours (Zhou et al. 2018). This theory helps to understand employees' decision to interpret how their organisation would support and compensate them in events that require a need for an ethical action to be taken. As such, it would increase the 
employees' willingness to become more transparent in discussing their organisational problems. Zhou et al. (2018) argued that a perceived healthy ethical climate would improve employees' capacity for moral judgement. A perceived healthy ethical climate would lead to positive whistleblowing norms.

As employees become familiarised with a healthy ethical climate, they will not perceive whistleblowers as complainers who would spread gossip about the organisation. Instead, they become employees who think that they have detected illegal behaviour and would like to see it stopped - and in many cases, they assume that their superiors would appreciate them sharing this crucial information to them (Near \& Miceli, 2016). When employees operate in an ethical climate, they are less likely to engage in misconduct (Mayer, Kuenzi \& Greenbaum, 2010).

However, that might not be the case. A study on police agencies found that a friendship or team climate demonstrates a capacity to predict willingness to blow the whistle, but generally fails to predict the frequency of blowing the whistle (Rothwell \& Baldwin, 2007). With longer period of service employees have more time to develop strong bonds and friendships among them that reduces the probability for them to report on their own colleagues. As they become more familiarised and exposed to agency misconduct, some senior employees might develop a cynicism that fosters an indifference towards whistleblowing. Whistleblowing tendencies among senior employees might also be disputed by younger employees who tend to report misconduct because they are less invested to their organisation, thus becoming less at risk (Ralin, 1987).

\section{Methodology}

The current study mainly refers to previous literature to discuss on previous issues relating fraud and how whistleblowers has been able to offer help in mitigating these fraud cases.

\section{Discussion: Whistleblowers as Primary Information Provider to Possible Red Flags of Fraud}

Whistleblowers in U.S. firms seem to be more daring compared to Asian whistleblowers, in taking up whistleblowing actions (Park, Rehg \& Lee, 2005). According to Ghani, Galbreath and Evans (2011), one of the probable explanations to this situation could be the perception of whistleblowing. For example, whistleblowing is unacceptable conduct in countries such as China, Japan and Hong Kong (Bond, 1996; Fukuyama, 1995; Redding, 1990). Whistleblowing is also not a common way of 
reporting illegal behaviour within organisations in Malaysia (Ngui, 2005). PricewaterhouseCoopers (2003), in its Global Economic Crime Survey, reported that 23 per cent of large Malaysian companies are subjected to wrongdoing in terms of unreported fraud. In their more recent Global Economic Crime Survey, PricewaterhouseCoopers (2014) mentioned that whistleblowing mechanisms remain underused in the financial service sector. They suggested in the report that the underutilisation of whistleblowing mechanism could be due to the greater dependencies placed on process-type detection methods in the industry, which encourages complacency and reduces the perceived need for individual integrity and accountability to come to the fore. Also, whistleblowing tends to be a last resort option for employees to raise their concerns and issues regarding suspicious business activities inside their organisation (PricewaterhouseCoopers, 2014).

Through another survey conducted by KPMG (2009), 25 per cent of fraud cases were discovered from anonymous letters, hence highlighting the importance of whistleblowing. According to Mustapha and Siaw (2012), over 30 countries have now implemented specific actions to protect whistleblowers, while others have implemented protection via law enforcement, for instance, modifications on labour laws or public sector employment rules. In Malaysia, the Whistleblower Protection Act (WPA) was implemented in 2010 for public and private sectors (Meng \& Fook, 2011). The act was implemented to encourage disclosure of information about corruption (including bribery or embezzlement) or improper behaviour to provide security to whistleblowers from any harmful effect due to the disclosure of information (MACC, 2016). A study conducted by Joseph, Gunawan, Sawani, Rahmat, Noyem and Darus (2016) indicated that out of 24 Malaysian companies and 34 Indonesian companies which participated in the ACCA Sustainability Reporting Award (MaSRA) 2011, 50 per cent of Malaysian companies had acknowledged the existence of whistleblowing policy in their companies, whereas, for Indonesian companies, the acknowledgement is at 70.6 per cent. Meanwhile, 37.5 per cent of Malaysian companies and 64.7 per cent of Indonesian companies had whistleblowing practices implemented in their companies.

Within the context of the public sector, Salleh and Yunus (2015) found that employees would only be motivated to become whistleblowers if they become aware of the seriousness and materiality of the committed wrongdoings. This is because they are guided by values which are in line with the general public's interest in the common good. 


\section{Conclusions}

Reviewing the literature related to fraud in higher education institutions, we found that nearly all whistleblowing-related research had focused on disclosures or reporting of immoral conduct of a superior. Direct empirical evidence on proposed relationships between individual characteristics and their decisions to disclose or report the unethical acts of their peer group members is still lacking (Barnett et al., 1996). Prior research relating to peer reporting, on the other hand, has emphasised the contextual factors that seem to influence peer reporting decisions such as role responsibility, group interests, and justice evaluations (Trevino \& Victor, 1992; Victor, Trevino, \& Shapiro, 1993). However, there is a deficiency of such researches in Malaysia, especially in the government sector, as most of the previous whistleblowing studies were conducted on organisations in the private sector (Bakar, Ismail \& Mamat, 2008; Mustapha \& Siaw, 2012).

In making decisions on whether to whistleblow or not, the issue of whether the individual factors influence the intention to whistleblow is always asked. Profit and non-profit organisations which are victimised by fraudulent activities and the fact that whistleblowing is a widely held device in identifying fraud motivates a person to decide whether to whistleblow or not. However, individuals who are aware of the unlawful activity of his or her peer group members would face a challenging ethical dilemma. They can ignore these wrongdoings and do nothing at all, or otherwise, they could talk to other employees and make a report internally or outside of the organisation. Other than that, they could also confront the offender directly and try to encourage him or her to undo their inappropriate actions. Alternatively, they may choose an alternative to "peer reporting", which encompasses the revelation of objectionable actions to someone with a perceived authority to stop the activity. Knowing the benefits of whistleblowing is crucial in creating a better workplace and builds robust internal control in a firm, thereby ensuring business prosperity.

However, according to U.S Securities and Exchange Commission's (2014) report to Congress on the Frank-Dodd Whistleblower Programme, the number of whistleblowing tips received for the period from 2011 to 2013 had decreased from 150 in 2011 to 12 in 2014. Lavena (2013) agreed that whistleblowing is a rare event within most federal agencies, adding that the existence of covering up fraudulent acts and providing threats to whistleblowers are factors as to why an individual decided not to whistleblow. With fraud cases escalating especially in universities, accounting professionals and account department staff are exposed to ethical dilemmas regularly and could uncover wrongdoing regarding 
their peers, possibly even before the effects are so disastrous that an organisation's viability is in question. For that reason, further understanding of issues and the possible positive impacts on whistleblowing should be gathered and tested empirically. The discussion provided from this study on issues of fraud in Malaysian higher education institutions and the important role for individuals to blow the whistle as soon as they sense red flags is hoped to provide a useful guide for organisations in designing distinct and unprejudiced whistleblowing hotlines to stop illegal organisational behaviour internally.

\section{Acknowledgement}

Authors would like to acknowledge all supports (Grant No. 600RMI/ARI_IRES 5/3(0042/2016)) provided by Accounting Research Institute (ARI), Universiti Teknologi MARA, Malaysia and Ministry of Higher Education, Malaysia.

\section{References}

ACFE. (2014). Report to the nations on occupational fraud and abuse. 2014 Global fraud study. Retrieved from https://www.acfe.com/

Albrecht, W., Albrecht, C., Albrecht, C., \& Zimbelman, M. (2008). Fraud examination. Cengage Learning.

Auditor General Malaysia (2008, October). Dealing with public sector fraud: enhancing integrity and transparency in government financial management. Paper presented at an international conference for Economic Crime in Asia: A Global Perspective, Malaysia.

Bakar, N.B.A, Ismail, S., \& Mamat, S. (2008). Ethics of future accounting professionals: Evidence from Malaysia. Journal of Financial Reporting and Accounting, 6(1), 21-33.

Barnett, T., Bass, K., \& Brown, G. (1996). Religiosity, ethical ideology, and intentions to report a peer's wrongdoing. Journal of Business Ethics, 15(11), 1161-1174.

Bjørkelo, B., Einarsen, S., \& Matthiesen, S. B. (2010). Predicting proactive behaviour at work: Exploring the role of personality as an antecedent of whistleblowing behaviour. Journal of Occupational and Organizational Psychology, 83(2), 371-394.

Boatright, J.R. (2000). Ethics and the conduct of business. Upple Saddler River, NJ: Prentice Hall.

Bond, M. (1996). The handbook of Chinese psychology. London: Oxford.

Cooper, D.J., Everett, J., \& Neu, D. (2005). Financial scandals, accounting change and the role of accounting academics: A perspective from North America. European Accounting Review, 14(2), 373-382.

Courtemanche, G. (1988). The ethics of whistle blowing. The Internal Auditor, 45(1), 3641.

Dasgupta, S., \& Kesharwani, A. (2010). Whistleblowing: A survey of literature. IUP Journal of Corporate Governance, 9(4), 57. 
Deegan, C. (2007). Organizational legitimacy as a motive for sustainability reporting. In Unerman, J., Bebbington, J., O'Dwyer, B. (Eds.), Sustainability Accounting and Accountability. Routledge, Oxon, 149,127.

Eaton, T.V., \& Akers, M.D. (2007). Whistleblowing and good governance. The CPA Journal, 77(6), 66-71.

Erkmen, T., Özsözgün Çalışkan, A., \& Esen, E. (2014). An empirical research about whistleblowing behavior in accounting context. Journal of Accounting and Organizational Change, 10(2), 229-243.

Financial Action Task Force (FATF) (2015). Mutual Evaluation Report Malaysia (2015). Retrieved from http://www.fatf-gafi.org/

Flack, T., \& Ryan, C. (2005). Financial reporting by Australian nonprofit organisations: Dilemmas posed by government funders. Australian Journal of Public Administration, 64(3), 69-77.

Fukuyama, F. (1995). Trust. New York: Free Press.

Ghani, N. A., Galbreath, J., \& Evans, R. (2011). Predicting whistle-blowing intention among supervisors in Malaysia. Paper presented at the Annual Summit on Business and Entrepreneurial Studies (ASBES 2011).

Golden, T. W., Skalak, S., \& Clayton, M. (2006). A guide to forensic accounting investigation. New York: McGraw-Hill.

Government Accountability Project (2019). Shameful Treatment of Whistleblower Who Exposed Pentagon Failure to Protect Troops in Iraq. Retrieved from https://www.whistleblower.org/

Higher Education Funding Council for England (HEFCE) (2015). Fraud updates. Retrieved from http:/ / www.hefce.ac.uk/

Integrated approach puts Malaysia on right track in fighting corruption. (2014, April 30). Borneo Post Online. Retrieved from http:/ / www.theborneopost.com/

Ismail, S., \& Abu Bakar, N. B. (2011). Reporting practices of Malaysian public universities: The extent of accountability disclosure. African Journal of Business Management, 5(15), 6366-6376.

Jaeggi, O. (2014). How non-profit organisations use reputational risk management. Retrieved from http://sloanreview.mit.edu/

Joseph, C., Gunawan, J., Sawani, Y., Rahmat, M., Noyem, J.A., \& Darus, F. (2016). A comparative study of anti-corruption practice disclosure among Malaysian and Indonesian Corporate Social Responsibility (CSR) best practice companies. Journal of Cleaner Production, 112, 2896-2906.

KPMG (2009). KPMG Malaysia Fraud Survey Report 2009. Retrieved from https://www.kpmg.com/

Lavena, C. F. (2013). Deciding to blow the whistle: how individual and organizational factors influence the reporting of wrongdoing in the federal government (Doctoral dissertation, Rutgers University-Graduate School-Newark).

MacNab, B. R., \& Worthley, R. (2008). Self-efficacy as an intrapersonal predictor for internal whistleblowing: A US and Canada examination. Journal of Business Ethics, $79(4), 407-421$.

Malaysian Anti-Corruption Commission (MACC). (2016). Education: What is corruption? Retrieved from http://www.sprm.gov.my/

Meng, T.P., \& Fook, O.S. (2011). Comparative analysis of whistleblower protection legislations in England, USA and Malaysia. African Journal of Business Management, 5(27), 11246. 
Mayer, D. M., Kuenzi, M., \& Greenbaum, R. L. (2010). Examining the Link Between Ethical Leadership and Employee Misconduct: The Mediating Role of Ethical Climate. Journal of Business Ethics, 95, 7-16.

Meyer, J. W., \& Rowan, B. (1977). Institutionalized organizations: Formal structure as myth and ceremony. American Journal of Sociology, 340-363.

Ministry of Finance (2015). Retrieved from http:/ / www.treasury.gov.my/

Ministry of Higher Education (MOHE) (2015). Public Institutions of Higher Education (PIHE). Retrieved from http://www.mohe.gov.my/

Murawski, J. (1995). Former United Way chief gets 7 years in jail; Sentence praised by charities. Chronicle of Philanthropy, 12, 37-38.

Mustapha, M. \& Siaw, L.S. (2012). Will final year accountancy students whistle blow? A Malaysian case. International Journal of Trade, Economics and Finance, 3(5), 327331.

Nader, R., Petkas, P. J., \& Blackwell, K. (Eds.). (1972). Whistle blowing: The report of the conference on professional responsibility (pp. 39-146). New York: Grossman Publishers.

Nasir, N. M., Othman, R., Said, J., \& Ghani, E. K. (2009). Financial reporting practices of charity organisations: A Malaysian evidence. International Bulletin of Business Administration, 6, 19-27.

Ngui, C. Y. K. (2005). Fighting fraud. ProQuest Asian Business and Reference database, from ProQuest Asian Business and Reference database.

Omar, N., \& Abu Bakar, K.M. (2012). Fraud prevention mechanisms of Malaysian government-linked companies: An assessment of existence and effectiveness. Journal of Modern Accounting and Auditing, 8(1), 15-31.

Organisation for Economic Co-operation and Development (OECD). (2012, July). Whistleblower protection: encouraging reporting. Retrieved from http://www.oecd.org/

Othman, R., Ali, N., Omar, N., \& Abdul Rahman, R. (2012). Practical challenges in managing non-profit organizations (NPO): Tales from two neighbouring countries. International Bulletin of Business Administration, 2012(13), 6-23.

Park, H., Blenkinsopp, J., Oktem, M. K., \& Omurgonulsen, U. (2008). Cultural orientation and attitudes toward different forms of whistleblowing: A comparison of South Korea, Turkey, and the UK. Journal of Business Ethics, 82(4), 929-939.

Park, H., Rehg, M.T., \& Lee, D. (2005). The influence of confucian ethics and collectivism on whistleblowing intentions: A study of South Korean public employees. Journal of Business Ethics, 58(4), 387-403.

Peltier-Rivest, D. (2014). Fraud magazine (back to school). Retrieved from http:/ / www.fraud-magazine.com/

PricewaterhouseCoopers (2003). Economic crime survey 2003. Retrieved from https://www.pwc.ch/

PricewaterhouseCoopers (2014). Economic crime survey 2014. Retrieved from https://www.pwc.com/

Ralin, J. A. (1987). The Professional as the Executive's Ethical Aide-De-Camp, Academy of Management Executive, 1, 171-182.

Redding, G. (1990). The spirit of Chinese capitalism. New York NY: Walter de Gruyter. Rezaee, Z. (2002). Financial statement fraud: prevention and detection. John Wiley \& Sons. 
Rothwell, G. R., \& Baldwin, J. N. (2007). Ethical climate theory, whistle-blowing, and the code of silence in police agencies in the State of Georgia. Journal of Business Ethics, 70, 341-361.

Salleh, K., \& Yunus, N. S. (2015). Encouraging factors for whistleblowing in public sector: Malaysian case evidence. Paper presented at the International Conference on Accounting Studies.

Shawver, T., \& Clements, L. H. (2008). Whistleblowing: Factors that contribute to management accountants reporting questionable dilemmas. Management Accounting Quarterly, 9(2).

Stecklow, S. (1997). New era's Bennett gets 12 years in prison for defrauding charities. Wall Street Journal, 23, B13.

Stittle, J. (2002). UK corporate ethical reporting-A failure to inform: Some evidence from company annual reports. Business and Society Review, 107(3), 349-370.

Stone, M., \& Starkey, M. (2011). The possible impact of university corruption on customers' ethical standards. Journal of Database Marketing and Customer Strategy Management, 18(3), 154-170.

Teo, H., \& Caspersz, D. (2011). Dissenting discourse: Exploring alternatives to the whistleblowing/silence dichotomy. Journal of Business Ethics, 104(2), 237-249.

Thornburg, D. (1997). Adelphi, weathering crisis, will endure. Newsday, March, 13, A57.

Transparency International (2013). Global Corruption Report: Education. Retrieved from http://www.transparency.org/

Trevino, L.K., \& Victor, B. (1992). Peer reporting of unethical behavior: A social context perspective. Academy of Management Journal, 35(1), 38-64.

U.S. Securities \& Exchange Commission (2014). 2014 Report to Congress on the FrankDodd Whistleblower Program. Retrieved from http:/ / www.sec.gov/

Victor, B., Trevino, L.K., \& Shapiro, D.L. (1993). Peer reporting of unethical behavior: The influence of justice evaluations and social context factors. Journal of Business Ethics, 12(4), 253-263.

Weisbrod, B. A. (1997). The future of the nonprofit sector: Its entwining with private enterprise and government. Journal of Policy Analysis and Management, 16(4), 541555.

Zhou, L., Liu, Y., Chen, Z., \& Zhao, S. (2018) Psychological mechanisms linking ethical climate to employee whistle-blowing intention. Journal of Managerial Psychology, 33(2), 196-213. 